\title{
PKC-theta-mediated signal delivery from the TCR/CD28 surface receptors
}

\author{
Noah Isakov ${ }^{1}$ and Amnon Altman ${ }^{2}$ \\ 'The Shraga Segal Department of Microbiology and Immunology, Faculty of Health Sciences and the Cancer Research Center, Ben-Gurion \\ University of the Negev, Beer Sheva, Israel \\ 2 Division of Cell Biology, La Jolla Institute for Allergy and Immunology, La Jolla, CA, USA
}

\section{Edited by:}

Nick Gascoigne, Scripps Research Institute, USA

\section{Reviewed by:}

Balbino Alarcon, Consejo Superior de Investigaciones Cientificas, Spain

Salvatore Valitutti, INSERM, France

\section{*Correspondence:}

Noah Isakov, The Shraga Segal Department of Microbiology and Immunology, Faculty of Health Sciences and the Cancer Research Center, Ben-Gurion University of the Negev, P.O. Box 653, Beer Sheva 84105, Israel. e-mail:noah@bgu.ac.il
Protein kinase $\mathrm{C}$-theta $(\mathrm{PKC} \theta$ ) is a key enzyme in T lymphocytes, where it plays an important role in signal transduction downstream of the activated T cell antigen receptor (TCR) and the $\mathrm{CD} 28$ costimulatory receptor. Interest in $\mathrm{PKC} \theta$ as a potential drug target has increased following recent findings that PKC $\theta$ is essential for harmful inflammatory responses mediated byTh2 (allergies) and Th17 (autoimmunity) cells as well as for graft-versus-host disease (GvHD) and allograft rejection, but is dispensable for beneficial responses such as antiviral immunity and graft-versus-leukemia (GvL) response. TCR/CD28 engagement triggers the translocation of the cytosolic PKC $\theta$ to the plasma membrane (PM), where it localizes at the center of the immunological synapse (IS), which forms at the contact site between an antigen-specific T cell and antigen-presenting cells (APC). However, the molecular basis for this unique localization, and whether it is required for its proper function have remained unresolved issues until recently. Our recent study resolved these questions by demonstrating that the unique $\mathrm{V} 3$ (hinge) domain of PKC $\theta$ and, more specifically, a proline-rich motif within this domain, is essential and sufficient for its localization at the IS, where it is anchored to the cytoplasmic tail of CD28 via an indirect mechanism involving Lck protein tyrosine kinase (PTK) as an intermediate. Importantly, the association of PKC $\theta$ with CD28 is essential not only for IS localization, but also for PKC $\theta$-mediated activation of downstream signaling pathways, including the transcription factors NF-KB and NF-AT, which are essential for productive T cell activation. Hence, interference with formation of the PKC $\theta-$ Lck-CD28 complex provides a promising basis for the design of novel, clinically useful allosteric PKC $\theta$ inhibitors. An additional recent study demonstrated that TCR triggering activates the germinal center kinase (GSK)-like kinase (GLK) and induces its association with the SLP-76 adaptor at the IS, where GLK phosphorylates the activation loop of $\mathrm{PKC} \theta$, converting it into an active enzyme. This recent progress, coupled with the need to study the biology of PKC $\theta$ in human T cells, is likely to facilitate the development of PKC $\theta$-based therapeutic modalities for $\mathrm{T}$ cell-mediated diseases.

Keywords: protein kinase C-theta, PKC $\theta$, CD28, Lck, signal transduction, costimulation

\section{INTRODUCTION}

Protein kinase C-theta $(\mathrm{PKC} \theta)$ is a key regulator of signal transduction in activated $\mathrm{T}$ cells that is linked to multiple pathways downstream of the $\mathrm{T}$ cell antigen receptor (TCR; Isakov and Altman, 2002). Engagement of the TCR and the resulting formation of diacylglycerol (DAG) are sufficient for promoting PKC $\theta$ recruitment to cell membranes (Monks et al., 1997, 1998). However, localization of $\mathrm{PKC} \theta$ to the immunological synapse (IS) is entirely dependent on the concomitant ligation of the CD28 coreceptor (Huang et al., 2002). Localization of PKC $\theta$ at the center of the IS is essential for activation of signaling pathways that promote $\mathrm{T}$ cell-dependent immune responses against distinct antigens and pathogens. While the recruitment of PKC $\theta$ to the IS of TCR/CD28 engaged T cells has been extensively studied, information on the molecular basis for this highly selective process has been relatively scarce until recently. The present manuscript provides background information on the molecules involved in this process and describes in more detail the studies that clarified a new mechanism by which PKC $\theta$ is being recruited to the center of the IS and is essential for the induction of PKC $\theta$-dependent activation signals.

\section{THE PKC FAMILY}

Protein kinase $\mathrm{C}$ was discovered by Nishizuka and colleagues, who demonstrated a new kinase that undergoes activation by limited proteolysis (Inoue et al., 1977), or by translocation to the plasma membrane (PM), where it associates with specific cofactors (Takai et al., 1979). The membrane-associated PKC-activating factor turned to be DAG (Kishimoto et al., 1980). DAG, together with inositol 1,4,5-trisphophate $\left(\mathrm{IP}_{3}\right)$, are products of phospholipase C-mediated hydrolysis of the membrane phospholipid, phosphatidylinositol 4,5-bisphosphate ( $\mathrm{PIP}_{2}$; Berridge and Irvine, 1984; Nishizuka, 1984). These two second messengers transduce signals from a plethora of activated receptors: the hydrophobic 
DAG remains bound to the cell membrane where, in addition to PKC, it activates effector molecules such as RasGRP, a guanine nucleotide exchange factor (GEF) for Ras (Lorenzo et al., 2000), while the hydrophilic $\mathrm{IP}_{3}$ diffuses through the cytosol and binds $\mathrm{IP}_{3}$-receptors, which function as ligand-gated $\mathrm{Ca}^{2+}$ channels in the endoplasmic reticulum (ER), thereby triggering the release of free $\mathrm{Ca}^{2+}$ ions into the cytoplasm (Takai et al., 1979; Khan et al., 1992; Bourguignon et al., 1994). The utilization of phorbol esters, which mimic the activity of DAG, together with $\mathrm{Ca}^{2+}$ ionophores, demonstrated that PKC also plays an essential role in the induction of T lymphocyte proliferation (Truneh et al., 1985; Isakov and Altman, 1987) and reactivation of effector cytotoxic T cells (Isakov and Altman, 1985; Isakov et al., 1987).

Protein kinase $\mathrm{C}$ enzymes transduce a myriad of signals from a large number of cell surface receptors that are coupled to phospholipase $\mathrm{C}$ and phospholipid hydrolysis. They regulate the function of effector molecules by phosphorylating specific serine and threonine residues. The PKC family includes 10 structurally and functionally related isoforms (for more details, see the first review by Pfeifhofer-Obermair et al., 2012), grouped into three subfamilies based on the composition of their regulatory domains and their respective cofactor requirements (Newton, 1995; Mellor and Parker, 1998). The first subfamily includes conventional PKCs (cPKC; $\alpha, \beta I, \beta I I, \gamma)$ that are regulated via two DAG-binding $\mathrm{C} 1$ domains organized in tandem near the cPKC amino terminus (Hurley et al., 1997; Johnson et al., 2000; Ho et al., 2001) and an adjacent $\mathrm{Ca}^{2+}$ and phospholipid-binding $\mathrm{C} 2$ domain (Nalefski and Falke, 1996; Johnson etal., 2000). The second group includes novel PKCs (nPKC; $\delta, \varepsilon, \eta, \theta$ ) that are DAGdependent, but $\mathrm{Ca}^{2+}$ and phospholipid independent for their activity. The third group includes atypical PKCs (aPKC: $\zeta, \lambda / \iota$ ) that are DAG-, $\mathrm{Ca}^{2+}$-, and phospholipid-independent. While PKC enzymes are involved in metabolic processes in different cell types, many studies implicate PKC enzymes in signal transduction networks that convert environmental cues into cellular actions (Rosse etal., 2010). Six of the PKC isoforms, including $\mathrm{PKC} \alpha, \delta, \varepsilon, \eta, \theta$, and $\zeta$ are expressed at varying amounts in T cells (Meller et al., 1999). Immunological studies using different genetic models and pharmacological drugs indicated that distinct PKC isoforms are required for different aspects of the activation and effector functions of $\mathrm{T}$ cells. The results suggest that distinct PKC isoforms may serve as drug targets for different $\mathrm{T}$ cell mediated adaptive immune responses (Baier and Wagner, 2009).

\section{PROTEIN KINASE C-THETA}

Protein kinase C-theta is a $\mathrm{Ca}^{2+}$-independent $\mathrm{nPKC}$ isoform exhibiting a relatively selective pattern of tissue distribution, with predominant expression in T lymphocytes (Baier et al., 1993; Meller etal., 1999), platelets (Chang et al., 1993; Meller et al., 1998; Cohen et al., 2009), and skeletal muscle (Osada et al., 1992; Chang etal., 1993). It has a unique ability to translocate to the center of the IS of activated T cells (Monks et al., 1997, 1998) where its full activation requires the integration of TCR and CD28 costimulatory signals (Huang et al., 2002; Tseng et al., 2008; Yokosuka etal., 2008). Engagement of the TCR and the CD28 coreceptor initiates a series of PKC $\theta$-dependent signaling events leading to activation of transcription factors, including NF- $\kappa$ B, AP-1, and NF-AT, which are critical for $\mathrm{T}$ cell activation, proliferation and differentiation (Baier-Bitterlich et al., 1996; Coudronniere et al., 2000; Dienz et al., 2000; Lin et al., 2000; Sun et al., 2000; Pfeifhofer et al., 2003). Under certain activation conditions, PKC $\theta$ can translocate to the nucleus where it directly associates with chromatin and is involved in the regulation of microRNAs and T cell-specific inducible gene expression program (Sutcliffe et al., 2011). The exact mechanism by which the membrane-bound $\mathrm{PKC} \theta$ delivers signals to the nucleus has not been fully resolved but studies provided information on a number of effector molecules that operate along this pathway in activated $\mathrm{T}$ cells. These studies demonstrated that $\mathrm{PKC} \theta$ mediated regulation of NF- $\kappa \mathrm{B}$ activity involves the multisubunit inhibitor of $\kappa \mathrm{B}$ (IКB) kinase (IKK) complex (Coudronniere et al., 2000; Dienz et al., 2000; Khoshnan et al., 2000; Lin et al., 2000; Bauer et al., 2001).

An important upstream effector in the NF- $\kappa B$ signaling pathway is I $\mathrm{B} \alpha$, which binds NF- $\kappa \mathrm{B}$ in the cytoplasm of resting T cells and mask its nuclear localization signal (NLS), thereby preventing NF- $\kappa \mathrm{B}$ translocation to the nucleus (Mercurio et al., 1997; Regnier et al., 1997; Jacobs and Harrison, 1998). IKK-mediated phosphorylation of I $\mathrm{B} \alpha$ signals the protein for degradation (Karin, 1999), exposes the NF- $\kappa \mathrm{B}$ NLS and promotes NF- $\kappa \mathrm{B}$ translocation to the nucleus and the induction of NF- $\kappa \mathrm{B}$-mediated gene transcription. T cells from PKC $\theta$-deficient $\left(\mathrm{Prkcq}^{-/-}\right)$mice fail to respond to TCR stimulation with degradation of $\mathrm{I} \kappa \mathrm{B} \alpha$ (Sun et al., 2000), supporting the model whereby $\mathrm{PKC} \theta$ regulates $\mathrm{NF}-\kappa \mathrm{B}$ activity through its effect on IKK-IкB $\alpha$. Some of the effector molecules that link PKC $\theta$ to IKK have been identified and include the PKC $\theta$ substrate protein, caspase activation and recruitment domain (CARD) and membrane-associated guanylate kinase (MAGUK) domain-containing protein-1 (CARMA1). This scaffold protein is primarily expressed in lymphocytes (Bertin et al., 2001; Hara et al., 2003), where it links PKC $\theta$ to NF-кB activation in T cells (Ruland etal., 2001, 2003; Ruefli-Brasse et al., 2003; Xue et al., 2003). Phosphorylation of CARMA1 by PKC $\theta$ in TCR/CD28stimulated T cells, promotes CARMA1 association with the B-cell lymphoma/leukemia 10 (Bcl10) and mucosa-associated lymphoid tissue 1 (MALT1) proteins (Matsumoto et al., 2005; Sommer et al., 2005) leading to recruitment of the trimolecular complex to the IS (Gaide et al., 2002; Che etal., 2004; Hara et al., 2004) and activation of the IKK complex (McAllister-Lucas et al., 2001). Furthermore, overexpression of CARMA1, Bcl10, and MALT1 in T cells, followed by TCR/CD28 stimulation, resulted in the formation of a CARMA1-Bcl10-MALT1 trimolecular complex, where all three proteins were required for maximal activation of $N F-\kappa B$ (McAllister-Lucas et al., 2001; Ruland et al., 2001). It should be noted that in some studies (Khoshnan et al., 2000), but not others (Lin et al., 2000), PKC $\theta$ was found to directly associate with members of the IKK complex, particularly IKK $\beta$, suggesting the potential existence of an additional linear route from PKC $\theta$ to NF- $\kappa$ B. The transcription factor AP-1, similar to NF- $\kappa$ B, is a primary physiological target of PKC $\theta$ (Baier-Bitterlich et al., 1996; Li et al., 2004), while regulation of the NF-AT transcription factor requires cooperation between $\mathrm{PKC} \theta$ and calcineurin, a $\mathrm{Ca}^{2+}$ dependent serine/threonine phosphatase (Pfeifhofer et al., 2003). 
All three PKC $\theta$-regulated transcription factors have corresponding binding sites on the IL-2 gene promoter, and their binding to the IL-2 gene is essential for optimal IL-2 response (Isakov and Altman, 2002).

While PKC $\theta$-mediated regulation of $\mathrm{NF}-\kappa \mathrm{B}$ activity in TCR/CD28-stimulated $\mathrm{T}$ cells has been studied in great detail, PKC $\theta$ is also involved in the regulation of additional cellular functions, and physically associates with additional binding partners. Besides CARMA1, PKC $\theta$ physically associate with 14-3-3 $\tau$ (Meller et al., 1996), Cbl (Liu et al., 1999), Fyn (Ron et al., 1999), Lck (Liu et al., 2000), AKT (Bauer et al., 2001), moesin (Pietromonaco et al., 1998), PICOT (Witte et al., 2000), and the HIV nef protein (Smith et al., 1996). Some of these molecules (i.e., Lck) phosphorylate PKC $\theta$ and may affect its activity and/or subcellular distribution, while others, which serve as substrates for PKC $\theta$ (i.e., Cbl, 14-3-3 $\tau$ and moesin) may regulate cellular functions, such as cytoskeletal reorganization.

\section{DIFFERENTIAL REQUIREMENTS FOR PKC $\theta$ BY DISTINCT T CELL SUBPOPULATIONS}

Initial characterization of $\mathrm{PKC} \theta$-deficient $\mathrm{T}$ cells suggested the involvement of PKC $\theta$ in cellular responses leading to $\mathrm{T}$ cell activation, proliferation, and cytokine production (Sun et al., 2000; Pfeifhofer et al., 2003; Anderson et al., 2006). Subsequent in vitro and in vivo investigations and the analysis of $\mathrm{Prkcq}^{-/-}$mice in different disease models demonstrated differential requirements for PKC $\theta$ by distinct $\mathrm{T}$ cell subpopulations and during the induction of selected types of immune responses. Thus, PKC $\theta$ was found to be essential for the induction of Th2-type immune responses to allergens or helminth infection (Marsland et al., 2004; Salek-Ardakani et al., 2004) and the induction of Th17-mediated experimental autoimmune encephalomyelitis (EAE) that serves as a model of multiple sclerosis (Salek-Ardakani et al., 2005; Anderson et al., 2006; Tan etal., 2006; Marsland et al., 2007; Kwon etal., 2012), and other experimental autoimmune diseases (Anderson et al., 2006; Healy et al., 2006; Marsland etal., 2007; Chuang et al., 2011). In contrast, Th1-dependent mouse resistance to Leishmania major infection was intact in $\mathrm{Prkcq}^{-/-}$ mice (Marsland et al., 2004; Ohayon et al., 2007), and PKCO was dispensable for CTL-mediated protective antiviral responses, most likely reflecting compensation by innate immunity signals (Berg-Brown et al., 2004; Giannoni et al., 2005; Marsland et al., 2005, 2007; Valenzuela et al., 2009). Consistent with the in vivo findings, in vitro induction of CD4+ $\mathrm{T}$ cell polarization by optimal $\mathrm{T}$ cell-antigen-presenting cell (APC) coculture conditions, demonstrated a requirement for $\mathrm{PKC} \theta$ during Th2 and Th17 cell development, and only moderate effect of PKC $\theta$ on Th1 cell development (Marsland et al., 2004; Salek-Ardakani etal., 2004, 2005). Additional studies performed in Prkcq-/mice demonstrated the requirement for PKC $\theta$ in the induction of graft-versus-host $(\mathrm{GvH})$ and alloreactive T cell-mediated immune responses (Valenzuela et al., 2009). In contrast, PKC $\theta$-deficient T cells retained the ability to induce graft-versus-leukemia $(\mathrm{GvL})$ responses in allogeneic bone marrow (BM) transplanted mice (Valenzuela et al., 2009).

Protein kinase C-theta also contributes to allograft rejection, as shown by Manicassamy et al. (2008) using an adoptive transfer model. In these studies, $\mathrm{Rag}^{-/-}$mice reconstituted with $\mathrm{Prkcq}^{-/-}$ $\mathrm{T}$ cells were unable to reject cardiac allografts, in contrast to the acute allograft rejection observed in the wild-type $\mathrm{T}$ cell reconstituted $\mathrm{Rag}^{-/-}$mice. However, this was due to lack of PKC $\theta$ regulated expression of anti-apoptotic molecules, such as $\mathrm{Bcl}-\mathrm{x}_{\mathrm{L}}$, which led to apoptosis of the effector T cells; transgenic expression of Bcl- $\mathrm{x}_{\mathrm{L}}$ in Prkcq $^{-/-}$T cells restored their ability to reject the cardiac allografts. The rejection of cardiac allograft by $\mathrm{Prkcq}^{-/-}$mice was only slightly delayed (Manicassamy et al., 2008; Gruber et al., 2009), suggesting compensation by other PKC isoforms. Indeed, mice lacking both $\mathrm{PKC} \theta$ and $\mathrm{PKC} \alpha$, demonstrated a significantly delayed rejection of cardiac allografts (Gruber et al., 2009).

The overall positive role of $\mathrm{PKC} \theta$ in the activation of effector $\mathrm{T}$ cells $\left(\mathrm{T}_{\text {eff }}\right)$ and the promotion of adaptive immune responses raise questions about the nature of its function in regulatory $\mathrm{T}$ cells $\left(\mathrm{T}_{\text {reg }}\right)$ that suppress $\mathrm{T}_{\text {eff }}$ functions. This issue has recently been partially resolved by Zanin-Zhorov et al. (2010) who found that PKC $\theta$ mediates negative feedback on $\mathrm{T}_{\text {reg }}$ functions. Furthermore, activation of $\mathrm{T}_{\text {reg }}$ resulted in sequestration of $\mathrm{PKC} \theta$ away from the IS, and inhibition of PKC $\theta$ activity (using the C20 compound) increased the suppressive activity of $\mathrm{T}_{\text {reg }}$ (Zanin-Zhorov et al., 2010, 2011). In vivo studies demonstrated that $\mathrm{T}_{\text {reg }}$ development in the thymus of $\operatorname{Prkcq} \mathrm{I}^{-/}$mice is impaired leading to reduced numbers of $\mathrm{T}_{\text {reg }}$ cells in the periphery (SchmidtSupprian et al., 2004; Zanin-Zhorov et al., 2010, 2011), although activity of these mature PKC $\theta$-deficient $\mathrm{T}_{\text {reg }}$ cells was intact (Gupta et al., 2008).

\section{THE IMMUNOLOGICAL SYNAPSE}

Adaptive immune responses are dependent on the effective communication between antigen-specific T cells and APCs. At the very early phase of the activation response, $\mathrm{T}$ cells interact via their TCR with cognate peptide-MHC complexes on the surface of APCs and both cell types respond by redistributing their receptors/ligands to the contact area that rearranges as a platform for effective signaling (Dustin and Zhu, 2006). The IS, representing the interface between a T cell and an APC, is formed by specific protein microclustering (Yokosuka et al., 2005) and their segregation into one of two separate regions: a central core [central supramolecular activation clusters (cSMAC)], which contains the TCR and costimulatory receptors, and a peripheral region [peripheral supramolecular activation clusters (pSMAC)], which contains adhesion molecules, such as LFA-1 (Dustin, 2009). T cell surface receptor engagement triggers signaling cascades that result in the recruitment of multiple membrane-anchored and cytoplasmic effector molecules, including kinases, adaptor proteins, and cytoskeletal components, to the IS (Dustin et al., 2010). One of the most prominent proteins to be recruited to the IS of antigenresponding T cells is PKC $\theta$, which localizes at the cSMAC (Monks et al., 1997, 1998). Additional high-resolution imaging analysis by TIRF microscopy demonstrated that PKC $\theta$ colocalizes with CD28, and demonstrated that the cSMAC is divided into two structurally and functionally distinct compartments: a central TCR ${ }^{\text {high }}$ compartment, where signaling is terminated (Vardhana et al., 2010) and TCR-associated signaling complexes are internalized and degraded, and an outer TCR ${ }^{\text {low "ring" where PKC } \theta \text { and }}$ CD28 colocalize (Yokosuka et al., 2008). 


\section{CD28}

CD28 is a type 1 transmembrane glycoprotein that is constitutively expressed as a disulfide-linked homodimer on all CD4+ and CD8+ murine T cells and majority of CD4+ and CD8+ human peripheral blood T cells (Gross et al., 1990; Vallejo, 2005). The human CD28 precursor protein is 220 amino acids long (218 in mouse) and the mature protein possesses 202 amino acids (218 in mouse) due to cleavage of an amino-terminal leader sequence (18 and 19 amino acids in the human and mouse CD28, respectively). In addition, CD28 possesses a cytoplasmic tail of 41 amino acids (38 in mouse) that is critical for signal transduction and coreceptor-induced cell stimulation. Physiological activation of CD28 is mediated by one of two natural ligands expressed on the surface of APCs, CD80, and CD86, which directly associate with a conserved motif [MYPPPY (single amino-acid letter code)] in the extracellular region of CD28 (Kariv et al., 1996; Truneh et al., 1996). Engagement of CD28 provides costimulatory signals that complement or synergize with those provided by the TCR, leading to optimal activation of T cells (Thompson et al., 1989; Harding et al., 1992). CD28 engagement increases IL2 production (Thompson et al., 1989; Jain et al., 1995; Reichert et al., 2001) and IL-2 receptor expression (Shahinian et al., 1993), and provides survival signals by upregulating the anti-apoptotic protein, Bcl-X $\mathrm{L}_{\mathrm{L}}$ (Boise et al., 1993). In addition, CD28 synergizes with the TCR in providing potent signals for activation of c-Jun kinase (JNK), p38 MAP kinase, and IKK pathways (Su et al., 1994; Harhaj and Sun, 1998), and activation of the NFкB (Michel etal., 2000; Diehn etal., 2002) AP-1 (Rincon and Flavell, 1994) and NF-AT transcription factors (Michel et al., 2000; Diehn et al., 2002).

The positive role of CD28 in T cell activation was demonstrated in CD28-deficient ( $\left.C d 28^{-/-}\right) \mathrm{T}$ cells, in which TCR engagement in the absence of CD28 costimulation resulted in anergy and/or tolerance induction upon rechallenge with the same antigen (Appleman and Boussiotis, 2003). T cell proliferation and Th2type cytokine secretion were also severely impaired in $\mathrm{Cd} 28^{-/-}$ mice or wild-type mice treated with CD28 antagonists (Green et al., 1994; Lucas et al., 1995; Rulifson etal., 1997; Schweitzer et al., 1997; Gudmundsdottir et al., 1999). Furthermore, lack of CD28-mediated costimulation led to reduced immune responses against infectious pathogens (Shahinian et al., 1993; King et al., 1996; Mittrucker et al., 2001; Compton and Farrell, 2002) and allografts (Salomon and Bluestone, 2001) and impaired GvH disease (Via et al., 1996), contact hypersensitivity (Kondo et al., 1996), and asthma (Krinzman et al., 1996).

$\mathrm{T}$ cell receptor engagement in the absence of CD28 costimulation induces an unbalanced signaling response in which TCR-mediated $\mathrm{Ca}^{2+}$ influx predominates. This leads to activation of calcineurin which dephosphorylates NF-AT leading to its nuclear translocation and induction of a limited set of anergyassociated genes resulting in T cell anergy (Macian et al., 2004). $\mathrm{CD} 28$, in contrast to the TCR, does not induce a $\mathrm{Ca}^{2+}$ response (Lyakh et al., 1997). Instead, CD28-coupled costimulatory signals induce the activation of NF- $\kappa$ B and AP-1, and concomitant AP-1 association with NF-AT, conditions that promote IL-2 prod uction and rescue of the $\mathrm{T}$ cells from a state of anergy (Macian et al., 2004).

\section{SIGNALING DOWNSTREAM OF CD28}

CD28 delivers signals in activated $\mathrm{T}$ cells via its cytoplasmic tail, which has no intrinsic catalytic activity, but possesses several protein-protein interaction motifs that enable it to associate with enzymes and other effector molecules (Boise et al., 1993; see Figure 1). In resting T cells, non-phosphorylated CD28 associates with the serine/threonine protein phosphatase protein $2 \mathrm{~A}$ (PP2A), which dissociates from CD28 upon activation inducedphosphorylation of CD28 (Chuang et al., 2000). CD28 triggering by its ligands leads to phosphorylation of tyrosine residues (Raab etal., 1995; Teng etal., 1996; King et al., 1997) in the cytoplasmic tail of CD28, creating new docking sites for different effector molecules that initiate the activation of signaling cascades, and define the costimulatory functions of CD28 (Raab et al., 1995; Andres et al., 2004; Dodson et al., 2009).

The first motif in the human CD28 cytoplasmic tail, juxtaposed to the $\mathrm{PM}$, contains a $\mathrm{Y}^{173} \mathrm{MNM}$ sequence that undergoes tyrosine phosphorylation following the engagement of CD28 and serves as a binding site for the $\mathrm{SH} 2$ domain of $\mathrm{p} 85$, the regulatory subunit of the lipid kinase, phosphatidylinositol 3-kinase (PI3K; August and Dupont, 1994; Pages et al., 1994; Prasad et al., 1994; Truitt et al., 1994). The methionine residue at the +3 position confers specificity for p85 binding (Takeda et al., 2008), while the asparagine at the +2 position confers additional specificity for the SH2 domain of Grb2 and GADS (Songyang et al., 1993; Raab et al., 1995; Sanchez-Lockhart et al., 2004; Schneider et al., 1995; Harada et al., 2001). The relative concentration of PI3K, Grb2, and GADS at the vicinity of CD28 cytoplasmic tail, and the relative affinity of their $\mathrm{SH} 2$ domain for the phospho-Tyr ${ }^{173}$-containing

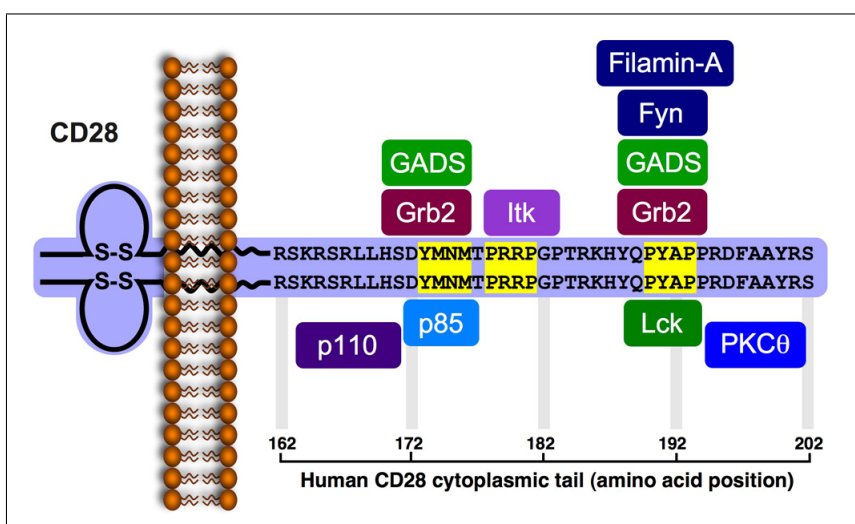

FIGURE 1 | Signaling motifs in the cytoplasmic tail of the human CD28 and binding partners. The human CD28 encodes a 220 amino acid-long protein (218 in the mouse) that includes a leader sequence of 18 residues (19 residues in the mouse). The mature protein (202 residues) possesses a 41 amino acid-long cytoplasmic tail that includes three potential protein-protein interaction motifs (highlighted in yellow). The phospho-Tyr ${ }^{173}$ within the YMNM motif serves as a docking site for the $\mathrm{SH} 2$-containg proteins, p85, Grb2 and GADS. The $\mathrm{P}^{178} \mathrm{RRP}$ motif can interact with the $\mathrm{SH} 3$ domain of Itk. The P190YAP motif can interacts with the $\mathrm{SH} 3$ domain of Grb2, GADS and Lck, as well as with filamin-A. Phosphorylation of Tyr ${ }^{191}$ within the PYAP motif creates a docking site for the Lck SH2 domain and enables PKC $\theta$ to interact via its $\mathrm{V} 3$ domain with the Lck SH3. Studies indicate that Tyr ${ }^{191}$ is important for CD28 and PKC $\theta$ localization to the CSMAC, and that the PYAP motif contributes to T cell activation and cytokine expression. 
motif likely determine which of the three potential binding partners interacts with the activated CD28 and, hence, the resulting functional outcome. A second, nearby motif possesses the $\mathrm{P}^{178} \mathrm{RRP}$ sequence, and serves as a binding site for the $\mathrm{SH} 3$ domain of IL-2-inducible T cell kinase (Itk; Marengere et al., 1997; Garcon et al., 2004). CD28-mediated activation of Itk is dependent on Lck (Gibson et al., 1996), but the actual role of Itk in CD28-induced costimulation is still controversial (Liao et al., 1997; Gibson et al., 1998; Yang and Olive, 1999; Li and Berg, 2005). A third, more distal, $\mathrm{P}^{190} \mathrm{YAP}$ motif serves as a potential docking site for several different effector molecules. These include filamin-A, an actin binding protein and a scaffold for lipid raft formation, which utilizes repeat 10 (amino acids 11581246) for interaction with CD28 (Tavano etal., 2006), Grb2 and GADS adaptor proteins, which bind the $\mathrm{P}^{190}$ YAP motif via their SH3 domain (Okkenhaug and Rottapel, 1998; Ellis et al., 2000), and the Lck and Fyn protein tyrosine kinases (PTKs; Hutchcroft and Bierer, 1994; zur Hausen et al., 1997; Holdorf et al., 1999; Tavano et al., 2004). Both Lck and Fyn were implicated in the early phase of the CD28 signaling pathway (August et al., 1994) and coexpression studies demonstrated that the two PTKs could phosphorylate CD28, primarily on $\operatorname{Tyr}^{173}$ at the $\mathrm{Y}^{173} \mathrm{MNM}$ motif, thereby increasing the binding of $\mathrm{p} 85-$ and Grb2-SH2 to CD28 (Raab et al., 1995). Lck and Fyn were also found to coimmunoprecipitate with CD28 from activated T cells (Hutchcroft and Bierer, 1994), where Lck interacted with the $\mathrm{P}^{190}$ YAP motif via its SH3 domain (Holdorf et al., 1999; Tavano et al., 2004), and Fyn interacted with the same motif using its SH2 domain (zur Hausen etal., 1997), although other studies indicated no interaction between CD28 and Fyn (Marengere et al., 1997). While presence of the two proline residues in the $\mathrm{P}^{190} \mathrm{YAP}$ motif predicts interaction with $\mathrm{SH} 3$-containg proteins, binding studies demonstrated that the Lck-SH3 domain interacts with relatively low affinity $\left(K_{\mathrm{d}}>1 \mu \mathrm{M}\right)$ with peptides that contain the $\mathrm{P}^{190}$ YAP motif and correspond to residues 188-202 of human CD28, or 186-196 of murine CD28, respectively (Hofinger and Sticht, 2005).

Other studies demonstrated that $\mathrm{Tyr}^{191}$ within the $\mathrm{P}^{190} \mathrm{YAP}$ motif is one of two major phosphorylation sites in CD28stimulated Jurkat $\mathrm{T}$ cells, and the only tyrosine residue within the CD28 cytoplasmic tail that is essential for delivery of costimulatory signals leading to CD69 expression and synthesis and secretion of IL-2 (Sadra et al., 1999). The latter findings raise the possibility that CD28 engagement-induced phosphorylation of $\mathrm{Tyr}^{191}$ creates a new and transient binding site for SH2containing proteins, possibly Lck, since CD28 and Lck were shown to colocalize at the cSMAC (Tavano et al., 2004; Kong et al., 2011). Binding studies provided further support for this hypothesis by showing that a CD28-derived peptide that possesses phospho-Tyr ${ }^{191}$ interacts with the Lck-SH2 domain with a relatively high affinity $\left(K_{\mathrm{d}}=2.13 \mu \mathrm{M}\right.$; Hofinger and Sticht, 2005), at the range of other SH2-ligand interactions (Bauer et al., 2004). This binding affinity is about three orders of magnitude stronger than that for the Lck-SH3 domain. High affinity binding of Lck-SH2 to $\mathrm{P}^{190}$ pYAP occurs despite the difference between this sequence and the phospho-YEEI sequence predicted to be the preferred binding site of the Lck-SH2 domain (Songyang et al., 1993). More recent studies indicated that PKC $\theta$ can also interact with the cytoplasmic tail of CD28, and that this interaction involves Lck as an intermediate molecule, as discussed below.

\section{CD28 AND THE IS}

Upon binding of its ligand, B7, CD28, similar to the engaged TCR, accumulates at the cSMAC of the IS although the two receptors initiates distinct but complementary signaling pathways. The transient recruitment of CD28 to the immature IS of TCR engaged T cells is very rapid and occurs within seconds of the onset of the calcium signal (Andres et al., 2004). Engagement of the TCR in $\mathrm{Cd} 28^{-/-}$T cells results in altered, diffuse pattern of distribution of PKC $\theta$ and LFA- 1 at the IS, suggesting an essential role for CD28 in the initiation and stabilization of the mature IS (Huang et al., 2002; Sanchez-Lockhart et al., 2004). Furthermore, in vivo blocking of CD28 impairs the activity of effector molecules, including PKC $\theta$ (Jang et al., 2008), and inhibits T cell-dependent immune responses (Linsley and Nadler, 2009). CD28 engagement promotes a cytoskeleton-dependent recruitment of cell surface receptors (Wulfing and Davis, 1998) and signaling molecules-containing lipid rafts that support building the IS and contribute to signal transduction from IS-residing receptors (Dustin and Shaw, 1999; Viola et al., 1999).

More recent studies demonstrated that in activated $\mathrm{T}$ cells, CD28 is recruited coordinately with the TCR to form microclusters at the cSMAC (Yokosuka et al., 2008). Upon progression of this initial step, the CD28 and TCR segregate to two spatially distinct subregions within the $\mathrm{CSMAC}$, a central TCR ${ }^{\text {high }}$ subregion, where signaling is terminated and TCR-associated signaling complexes are internalized and degraded, and an outer TCR ${ }^{\text {low }}$ annular form that contain CD28 clusters, as well as $\mathrm{PKC} \theta$. CD28 and $\mathrm{PKC} \theta$ were physically associated, as shown by $\mathrm{PKC} \theta$ coimmunoprecipitation with CD28 from a lysate of PMA-stimulated T cells (Yokosuka et al., 2008).

\section{PKC $\theta-C D 28$ INTERACTION AND RECRUITMENT} OF PKC $\theta$ TO THE IS

$\mathrm{T}$ cell receptor engagement polarizes $\mathrm{PKC} \theta$ and induce its recruitment to the IS, a response that is greatly augmented by CD28 ligation (Huang et al., 2002; Tseng et al., 2008; Yokosuka et al., 2008). Although the recruitment of $\operatorname{PKC} \theta$ to the center of the IS (cSMAC) of is well documented, information on the molecular basis for this highly selective localization has been relatively scarce. Early studies have shown that $\mathrm{PKC} \theta$ recruitment to the IS is indirectly dependent on the PI3K interaction motif within the CD28 cytosolic tail (Harada et al., 2001). Thus, mutation of $\mathrm{Met}^{173}$ within the mouse YMNM motif, which binds PI3K upon its tyrosine phosphorylation, resulted in decreased ability of CD28 to direct PKC $\theta$ recruitment to the cSMAC, and inhibited $\mathrm{PKC} \theta$-dependent activation of $\mathrm{NF}-\kappa \mathrm{B}$ to and the $I l 2$ gene (Sanchez-Lockhart et al., 2004).

Following the recently reported $\mathrm{PKC} \theta-\mathrm{CD} 28$ association in PMA-stimulated T cells (Yokosuka et al., 2008), we conducted a detailed structure-function analysis of this association in TCRstimulated $\mathrm{T}$ cells (Kong et al., 2011). We demonstrated that PKC $\theta$ physically associated with the cytoplasmic tail of CD28 
following TCR/CD28 costimulation. Taking advantage of the fact that $\mathrm{PKC} \delta$, the closest relative of $\mathrm{PKC} \theta$, does not translocate to the IS after T cell-APC interaction (Monks et al., 1997), we compared the amino acid sequence analysis of $\operatorname{PKC} \theta$ and $\operatorname{PKC} \delta$ and found that they diverged significantly only in their V3 (hinge) domain, corresponding to amino acids $\sim 291-378$ of human PKC $\theta$, suggesting a potential role for this region in targeting $\mathrm{PKC} \theta$ to the IS. Indeed, a V3-deletion mutant of PKC $\theta(\mathrm{PKC} \theta-\Delta \mathrm{V} 3)$ or an exchange mutant of $\mathrm{PKC} \theta$, in which the native $\mathrm{V} 3$ domain was replaced by the PKC $\delta \mathrm{V} 3$ domain, did not coimmunoprecipitate with CD28, and failed to translocate to the IS (Kong et al., 2011) and to activate PKC $\theta$-dependent reporter genes such as the $\mathrm{CD} 28$ response element (RE/AP). Conversely, the isolated V3 domain of PKC $\theta$ localized in the center of the IS and associated with CD28. Moreover, T cells recovered from mouse BM chimeras on a $P r k c q^{-/-}$background reconstituted with the same PKC $\theta$ mutants failed to proliferate and produce IL-2 in response to $\mathrm{CD} 3 / \mathrm{CD} 28$ costimulation, and their ability to upregulate CD69 or CD25 expression was reduced. Given the critical role of the V3 domain in directing the CD28 association and IS localization of PKC $\theta$, we argued that this domain will function as a dominant negative mutant by disrupting the activationdependent association between endogenous CD28 and PKC $\theta$. As expected, ectopic expression of the isolated $\mathrm{PKC} \theta \mathrm{V} 3$ domain blocked the recruitment of endogenous PKC $\theta$ to $\mathrm{CD} 28$ and the IS, and severely inhibited PKC $\theta$-dependent functions, including CD25 and CD69 upregulation, T cell proliferation and IL-2 production, and Th2 and Th17 (but not Th1) differentiation and inflammation.

Fine mapping of the PKC $\theta$ V3 domain identified an evolutionarily conserved proline-rich (PR) motif (ARPPCLPTP; corresponding to amino acid residues 328-336 of human $\mathrm{PKC} \theta$ ) within the $\mathrm{PKC} \theta-\mathrm{V} 3$ domain, which was required for $\mathrm{PKC} \theta-\mathrm{CD} 28$ association, PKC $\theta$ localization to the IS, and induction of PKC $\theta$ mediated functions. Insertion of this motif into the $\mathrm{V} 3$ domain of PKC $\delta$ enabled this altered PKC $\delta$ form to translocate to the IS and activate $\mathrm{PKC} \theta$-dependent signal. The two internal proline residues in this motif (Pro-331 and -334) were particularly critical in this regard (Kong et al., 2011).

In trying to more precisely define the nature of the inducible PKC $\theta$-Lck complex, we focused on the potential contribution of Lck kinase. This possibility was considered in view of previous studies demonstrating a functional relationship between CD28, PKC $\theta$, and Lck. First, in stimulated T cells, Lck can be recruited to the tyrosine-phosphorylated distal PR motif $\left(\underline{P}^{190} \mathrm{Y}^{\star} \mathrm{AP}\right)$ in the cytoplasmic tail of $\mathrm{CD} 28$ via its $\mathrm{SH} 2$ and $\mathrm{SH} 3$ domains, respectively (Miller et al., 2009; see Figure 2), This motif directs the colocalization of PKC $\theta$ and CD28 to the cSMAC (Yokosuka et al., 2008) and is apparently involved in additional biological functions, including the stabilization of IL-2 mRNA, reorganization of lipid rafts, and sustained autophosphorylation and activation of Lck at the IS (Holdorf et al., 2002; Sanchez-Lockhart et al., 2004; Dodson et al., 2009). Second, Lck phosphorylates and associates with PKC $\theta$, and mutation of the major Lck phosphorylation site on $\mathrm{PKC} \theta\left(\mathrm{Tyr}^{90}\right)$

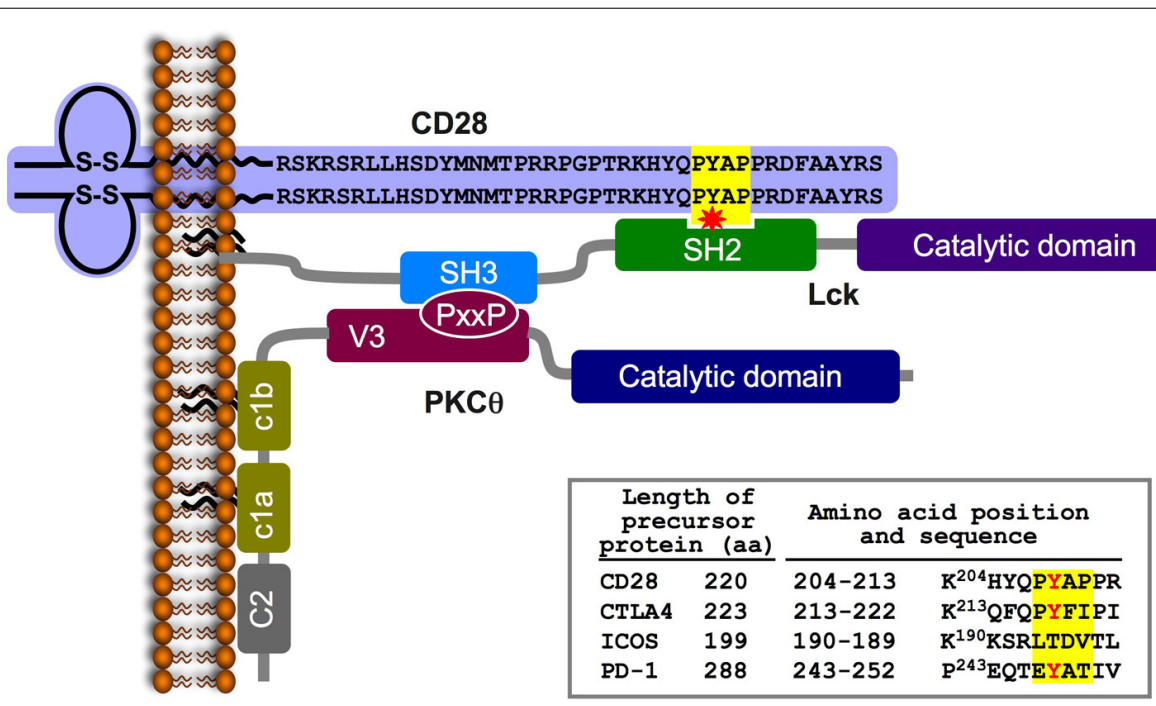

FIGURE 2 | A schematic model of the CD28-Lck-PKC $\theta$ tri-partite complex formed in TCR/CD28-stimulated T cells. TCR/CD28 engagement triggers the activation of tyrosine kinases and phosphorylation of multiple substrates, including the cytoplasmic tail of the CD28. Phosphorylation of a tyrosine within the PYAP motif ( $Y^{191}$ in the mature human CD28) forms a high affinity-binding site for the $\mathrm{SH} 2$ domain of the Lck PTK. Lck is an IS-residing molecule in activated T cells; it is tethered to the plasma membrane via its $\mathrm{N}$-terminal palmitic and myristic fatty acids (Paige et al., 1993), and is constitutively associated with the cytoplasmic tail of the IS-residing accessory molecules, CD4 or CD8 (Rudd etal., 1988, 1989; Veillette etal., 1988; Barber et al., 1989; Paige et al., 1993). Simultaneous activation of phospholipase $\mathrm{C}$ and hydrolysis of the membrane phospholipid $\left(\mathrm{PIP}_{2}\right)$ forms DAG, which enables PKC $\theta$ anchoring to the plasma membrane. Colocalization of $\mathrm{PKC} \theta$ and $\mathrm{CD} 28$ is regulated by an interaction between the PKC $\theta$ PXXP motif and the Lck-SH3 domain, which results in the formation of a trimolecular complex comprising CD28-Lck-PKC $\theta$. The inset table shows the amino acid sequence of a region within the cytoplasmic tail of the immature CD28 that includes the PYAP motif (on a yellow background) compared to homologous sequences of three additional members of the CD28 coreceptor family (obtained using the ClustalW multiple sequence alignment program). A partially conserved tyrosine is marked in red. 
inhibited PKC $\theta$-dependent activation events in stimulated $\mathrm{T}$ cells (Liu et al., 2000).

Our further analysis confirmed the physical and functional CD28-Lck-PKC $\theta$ link by demonstrating that Lck function as an intermediate to recruit $\mathrm{PKC} \theta$ to $\mathrm{CD} 28$ upon $\mathrm{T}$ cell stimulation. The Lck-SH3 domain interacted with the PR motif in the PKC $\theta$ V3 domain, while the Lck SH2 domain interacted with phospho-Tyr ${ }^{191}$ in the $\mathrm{P}^{190}$ YAP motif in the CD28 cytoplasmic tail. Taken together, the above findings demonstrate a unique signaling mode of CD28 and establish the molecular basis for the specialized localization and function of PKC $\theta$ in antigen-stimulated T cells.

\section{THE GLK-PKC $\theta$ LINK}

Recent studies demonstrated that recruitment of $\operatorname{PKC} \theta$ to the cSMAC in activated $\mathrm{T}$ cells is essential but not sufficient for the full activation of PKC $\theta$ and its downstream target molecules. These studies further showed that the germinal center kinase (GSK)-like kinase (GLK) also translocates to the IS of TCR-engaged T cells where it phosphorylates the activation loop of $\mathrm{PKC} \theta$, converting it into an active enzyme (Chuang et al., 2011). Of interest, however, despite the importance of PKC $\theta$ in the thymic development of natural regulatory T cells (nTregs; Schmidt-Supprian et al., 2004), GLK-deficient mice displayed normal nTreg development (Chuang et al., 2011). These results emphasize the important role of post-transcriptional regulation of $\mathrm{PKC} \theta$ that occurs at several steps and involve different checkpoints at distinct sites within the activated $\mathrm{T}$ cell.

\section{CONCLUSIONS AND FUTURE PERSPECTIVES}

Identification and characterization of the molecular mechanism by which PKC $\theta$ associates with CD28 and colocalizes with it at the cSMAC has provided important information relevant to the mechanism by which CD28 and PKC $\theta$ contribute to signal transduction in TCR/CD28-engaged T cells. These findings also raise new questions relevant to the mechanism of interaction of CD28 and $\mathrm{PKC} \theta$ and their specific role in the induction of distinct $\mathrm{T}$ cell-mediated immune responses. One obvious question relates to the mechanism by which PKC $\theta$ is sequestered away from the IS of activated $\mathrm{T}_{\text {reg }}$ cells. It would be interesting to determine whether a CD28-Lck-PKC $\theta$ tri-partite complex (Kong et al., 2011) occurs in $\mathrm{T}_{\text {reg }}$ cells, and determine the mechanism that enables PKC $\theta$ recruitment away from the $\mathrm{T}_{\text {reg }}$-APC contact area. A possible explanation for this process was provided by Yokosuka et al. (2010) showing that CTLA-4 competes with CD28 in recruitment to the cSMAC. In addition, it is not known whether PKC $\theta$ is involved in a second signal delivery during the costimulation of $\gamma \delta$ T cells (Ribot et al., 2011).

\section{REFERENCES}

Altman, A., and Kong, K.-F. (2012). PKC $\theta$ : a new target for selective immunosuppression. Exp. Rev. Clin. Immunol. 8, 205-208.

Anderson, K., Fitzgerald, M., Dupont, M., Wang, T., Paz, N., Dorsch, M., Healy, A., Xu, Y., Ocain, T., Schopf, L., Jaffee, B., and Picarella, D. (2006). Mice deficient in PKC

Despite the extensive amount of studies on the biology of PKC $\theta$ in mouse $\mathrm{T}$ cells, very little is known about its regulation and function in human $\mathrm{T}$ cells. This is a substantial gap that would need to be filled if PKC $\theta$ is destined to fulfill its promise as a clinically relevant drug target (Altman and Kong, 2012). As discussed earlier, the dependence of $\mathrm{T}$ cell-mediated deleterious autoimmune/inflammatory responses, including GvHD, on $\mathrm{PKC} \theta$, but its dispensable role in beneficial responses (antiviral immunity and GvL response) make it an attractive clinical drug target with potentially advantage over global immunosuppressive drugs such as calcineurin inhibitors (e.g., cyclosporine A), which have pronounced toxic side effects. Indeed, there has been considerable interest among pharmaceutical companies in developing small molecule selective PKC $\theta$ catalytic activity inhibitors, and AEB071, the most advanced of these compounds, which inhibits other PKC family members in addition to $\mathrm{PKC} \theta$, is currently in early clinical trials (Evenou et al., 2009).

Nevertheless, small molecule inhibitors of protein kinases often have toxic side effects because of their lack of absolute specificity, which reflects the relatively high conservation of catalytic domains within the protein kinase family, and even more so within the PKC family. Furthermore, since catalytic kinase inhibitors in current clinical use are ATP competitors, they need to be used at relatively high and potentially toxic concentrations in order to effectively compete with ATP, whose intracellular concentration is $\sim 1 \mathrm{mM}$. As a result, there has recently been considerable interest and progress in developing allosteric kinase inhibitors, which bind to sites other than the catalytic site in kinases and, thus, are likely to be much more selective and less toxic (Lamba and Ghosh, 2012). Our recent study (Kong et al., 2011) demonstrates a new potential approach for attenuating PKC $\theta$-dependent functions utilizing allosteric compounds based on the critical PR motif in the V3 domain of PKC $\theta$ that will block its Lckmediated association with CD28 and recruitment to the IS, which is obligatory for its downstream signaling functions. This new approach could serve as a basis for the development of new therapeutic agents that would selectively suppress undesired $\mathrm{T}$ cell-mediated inflammation and autoimmunity or prevent graft rejection, while preserving desired immunity, such as antiviral responses.

\section{ACKNOWLEDGMENTS}

This is manuscript number 1529 from the La Jolla Institute for Allergy and Immunology. Work in our laboratory is supported by the USA-Israel Binational Science Foundation, the Israel Science Foundation administered by the Israel Academy of Science and Humanities, and by NIH grant CA35299. Noah Isakov holds the Joseph H. Krupp Chair in Cancer Immunobiology.

domain are required for T helper type 2 differentiation. Nat. Immunol. 5, 435-442.

Appleman, L. J., and Boussiotis, V. A. (2003). T cell anergy and costimulation. Immunol. Rev. 192, 161-180.

August, A., and Dupont, B. (1994). CD28 of $\mathrm{T}$ lymphocytes associates with phosphatidylinositol 3-kinase. Int. Immunol. 6, 769-774.
August, A., Gibson, S., Kawakami, Y., Kawakami, T., Mills, G. B., and Dupont, B. (1994). CD28 is associated with and induces the immediate tyrosine phosphorylation and activation of the $\mathrm{Tec}$ family kinase ITK/EMT in the human Jurkat leukemic T-cell line. Proc. Natl. Acad. Sci. U.S.A. 91, 9347-9351. 
Baier, G., Telford, D., Giampa, L., Coggeshall, K. M., Baier-Bitterlich, G., Isakov, N., and Altman, A. (1993) Molecular cloning and characterization of PKC theta, a novel member of the protein kinase $\mathrm{C}$ (PKC) gene family expressed predominantly in hematopoietic cells. J. Biol. Chem. 268, 4997-5004.

Baier, G., and Wagner, J. (2009). PKC inhibitors: potential in T celldependent immune diseases. Curr. Opin. Cell Biol. 21, 262-267.

Baier-Bitterlich, G., Uberall, F., Bauer, B., Fresser, F., Wachter, H., Grunicke, H., Utermann, G., Altman, A., and Baier, G. (1996). Protein kinase Ctheta isoenzyme selective stimulation of the transcription factor complex AP-1 in T lymphocytes. Mol. Cell Biol. $16,1842-1850$

Barber, E. K., Dasgupta, J. D., Schlossman, S. F., Trevillyan, J. M., and Rudd, C. E. (1989). The CD4 and CD8 antigens are coupled to a protein-tyrosine kinase (p56lck) that phosphorylates the CD3 complex. Proc. Natl. Acad. Sci. U.S.A. 86, 3277-3281.

Bauer, B., Krumbock, N., Fresser, F., Hochholdinger, F., Spitaler, M. Simm, A., Uberall, F., Schraven, B., and Baier, G. (2001). Complex formation and cooperation of protein kinase $\mathrm{C}$ theta and Akt1/protein kinase B alpha in the NF-kappa B transactivation cascade in Jurkat $\mathrm{T}$ cells. J. Biol. Chem. 276, 3162731634.

Bauer, F., Hofinger, E., Hoffmann, S., Rosch, P., Schweimer, K., and Sticht, H. (2004). Characterization of Lckbinding elements in the herpesviral regulatory Tip protein. Biochemistry 43, 14932-14939.

Berg-Brown, N. N., Gronski, M. A., Jones, R. G., Elford, A. R., Deenick, E. K., Odermatt, B., Littman, D. R., and Ohashi, P. S. (2004). PKCtheta signals activation versus tolerance in vivo. J. Exp. Med. 199, 743-752.

Berridge, M. J., and Irvine, R. F. (1984) Inositol trisphosphate, a novel second messenger in cellular signal transduction. Nature 312, 315-321.

Bertin, J., Wang, L., Guo, Y., Jacobson, M. D., Poyet, J. L., Srinivasula, S. M., Merriam, S., DiStefano, P. S., and Alnemri, E. S. (2001) CARD11 and CARD14 are novel caspase recruitment domain (CARD) membrane-associated guanylate kinase (MAGUK) family members that interact with BCL10 and activate NFkappa B. J. Biol. Chem. 276, 1187711882.

Boise, L. H., Gonzalez-Garcia, M., Postema, C. E., Ding, L., Lindsten, T., Turka, L. A., Mao, X., Nunez, G., and Thompson, C. B. (1993). bcl-x, a bcl-2-related gene that functions as a dominant regulator of apoptotic cell death. Cell 74, 597-608.

Bourguignon, L. Y., Iida, N., Sobrin, L., and Bourguignon, G. J. (1994). Identification of an IP3 receptor in endothelial cells. J. Cell Physiol. 159, 29-34.

Chang, J. D., Xu, Y., Raychowdhury, M. K., and Ware, J. A. (1993). Molecular cloning and expression of a cDNA encoding a novel isoenzyme of protein kinase $\mathrm{C}$ (nPKC). A new member of the nPKC family expressed in skeletal muscle, megakaryoblastic cells, and platelets. J. Biol. Chem. 268 , 14208-14214.

Che, T., You, Y., Wang, D., Tanner, M. J., Dixit, V. M., and Lin X. (2004). MALT1/paracaspase is a signaling component downstream of CARMA1 and mediates $T$ cell receptor-induced NF-kappaB activation. J. Biol. Chem. 279, 1587015876

Chuang, E., Fisher, T. S., Morgan, R. W., Robbins, M. D., Duerr, J. M., Vander Heiden, M. G., Gardner, J. P., Hambor, J. E., Neveu, M. J., and Thompson, C. B. (2000). The CD28 and CTLA-4 receptors associate with the serine/threonine phosphatase PP2A. Immunity 13, 313-322.

Chuang, H. C., Lan, J. L., Chen, D. Y., Yang, C. Y., Chen, Y. M., Li, J. P., Huang, C. Y., Liu, P. E., Wang, X. and Tan, T. H. (2011). The kinase GLK controls autoimmunity and NFkappaB signaling by activating the kinase PKC-theta in T cells. Nat. Immunol. 12, 1113-1118.

Cohen, S., Braiman, A., Shubinsky, G., Ohayon, A., Altman, A., and Isakov N. (2009). PKC-theta is required for hemostasis and positive regulation of thrombin-induced platelet aggregation and alpha-granule secretion Biochem. Biophys. Res. Commun. 385 22-27.

Compton, H. L., and Farrell, J. P. (2002). CD28 costimulation and parasite dose combine to influence the susceptibility of BALB/c mice to infection with Leishmania major. J. Immunol. 168, 1302-1308.

Coudronniere, N., Villalba, M. Englund, N., and Altman, A. (2000). NF-kappa B activation induced by $\mathrm{T}$ cell receptor/CD28 costimulation is mediated by protein kinase C-theta. Proc. Natl. Acad. Sci. U.S.A. 97, 3394-3399.

Diehn, M., Alizadeh, A. A., Rando, O. J., Liu, C. L., Stankunas, K., Botstein, D., Crabtree, G. R., and Brown, P. O. (2002). Genomic expression programs and the integration of the CD28 costimulatory signal in T cell activation. Proc. Natl. Acad. Sci. U.S.A. 99, 11796-11801.

Dienz, O., Hehner, S. P., Droge, W., and Schmitz, M. L. (2000). Synergistic activation of NF-kappa B by functional cooperation between vav and PKCtheta in T lymphocytes. J. Biol. Chem. 275, 24547-24551.

Dodson, L. F., Boomer, J. S., Deppong, C. M., Shah, D. D., Sim, J., Bricker, T. L., Russell, J. H., and Green, J. M. (2009). Targeted knock-in mice expressing mutations of CD28 reveal an essential pathway for costimulation. Mol. Cell Biol. 29, 3710-3721.

Dustin, M. L., Chakraborty, A. K., and Shaw, A. S. (2010). Understanding the structure and function of the immunological synapse. Cold Spring Harb. Perspect. Biol. 2, a002311.

Dustin, M. L., and Shaw, A. S. (1999). Costimulation: building an immunological synapse. Science 283, 649-650.

Dustin, M. L., and Zhu, C. (2006) $\mathrm{T}$ cells like a firm molecular handshake. Proc. Natl. Acad. Sci. U.S.A 103, 4335-4336.

Dustin, M. L. (2009). The cellular context of T cell signaling. Immunity 30 482-492.

Ellis, J. H., Ashman, C., Burden, M. N., Kilpatrick, K. E., Morse, M. A., and Hamblin, P. A. (2000). GRID: a novel Grb-2-related adapter protein that interacts with the activated $\mathrm{T}$ cell costimulatory receptor CD28. J. Immunol. 164, 5805-5814.

Evenou, J. P, Wagner, J., Zenke, G., Brinkmann, V., Wagner, K., Kovarik, J., Welzenbach, K. A., Weitz-Schmidt, G., Guntermann, C., Towbin, H., Cottens, S., Kaminski, S., Letschka, T., Lutz-Nicoladoni, C., Gruber, T. Hermann-Kleiter, N., Thuille, N., and Baier, G. (2009). The potent protein kinase C-selective inhibitor AEB071 (sotrastaurin) represents a new class of immunosuppressive agents affecting early T-cell activation. J. Pharmacol. Exp. Ther. 330, 792-801.

Gaide, O., Favier, B., Legler, D. F., Bonnet, D., Brissoni, B., Valitutti, S., Bron, C., Tschopp, J., and Thome, M. (2002). CARMA1 is a critical lipid raft-associated regulator of TCR-induced NF-kappa B activation. Nat. Immunol. 3, 836-843.

Garcon, F., Ghiotto, M., Gerard, A., Yang, W. C., Olive, D., and Nunes, J. A. (2004). The SH3 domain of Tec kinase is essential for its targeting to activated CD28 costimulatory molecule. Eur. I. Immunol. 34, 1972 1980.

Giannoni, F., Lyon, A. B., Wareing, M. D., Dias, P. B., and Sarawar, S. R.
(2005). Protein kinase C theta is not essential for T-cell-mediated clearance of murine gammaherpesvirus 68. J. Virol. 79, 6808-6813.

Gibson, S., August, A., Branch, D., Dupont, B., and Mills, G. M. (1996). Functional LCK is required for optimal CD28-mediated activation of the TEC family tyrosine kinase EMT/ITK. J. Biol. Chem. 271, 70797083.

Gibson, S., Truitt, K., Lu, Y., Lapushin, R., Khan, H., Imboden, J. B., and Mills,G. B. (1998). Efficient CD28 signalling leads to increases in the kinase activities of the TEC family tyrosine kinase EMT/ITK/TSK and the SRC family tyrosine kinase LCK. Biochem. J. 330, 1123-1128.

Green, J. M., Noel, P. J., Sperling, A. I., Walunas, T. L., Gray, G. S., Bluestone, J. A., and Thompson, C. B. (1994). Absence of B7-dependent responses in CD28-deficient mice. Immunity 1 , 501-508.

Gross, J. A., St John, T., and Allison, J. P. (1990). The murine homologue of the T lymphocyte antigen CD28. Molecular cloning and cell surface expression. J. Immunol. 144, 32013210.

Gruber, T., Hermann-Kleiter, N., Pfeifhofer-Obermair, C., LutzNicoladoni, C., Thuille, N., Letschka, T., Barsig, J., Baudler, M., Li, J., Metzler, B., Nusslein-Hildesheim, B., Wagner, J., Leitges, M., and Baier, G. (2009). PKC theta cooperates with $\mathrm{PKC}$ alpha in alloimmune responses of T cells in vivo. Mol. Immunol. 46, 2071-2079.

Gudmundsdottir, H., Wells, A. D., and Turka, L. A. (1999). Dynamics and requirements of $\mathrm{T}$ cell clonal expansion in vivo at the single-cell level: effector function is linked to proliferative capacity. J. Immunol. 162, 5212-5223.

Gupta. S., Manicassamy, S., Vasu, C., Kumar, A., Shang, W., and Sun, Z. (2008). Differential requirement of PKC-theta in the development and function of natural regulatory $\mathrm{T}$ cells. Mol. Immunol. 46, 213-224.

Hara, H., Bakal, C., Wada, T., Bouchard, D., Rottapel, R., Saito, T., and Penninger, J. M. (2004). The molecular adapter Carmal controls entry of IkappaB kinase into the central immune synapse. J. Exp. Med. 200, 1167-1177.

Hara, H., Wada, T., Bakal, C., Kozieradzki, I., Suzuki, S., Suzuki, N., Nghiem, M., Griffiths, E. K., Krawczyk, C., Bauer, B., D’Acquisto, F., Ghosh, S., Yeh, W. C., Baier, G., Rottapel, R., and Penninger, J. M. (2003). The MAGUK family 
protein CARD11 is essential for lymphocyte activation. Immunity 18 , 763-775.

Harada, Y., Tanabe, E., Watanabe, R., Weiss, B. D., Matsumoto, A., Ariga, H., Koiwai, O., Fukui, Y., Kubo, M., June, C. H., and Abe, R. (2001). Novel role of phosphatidylinositol 3-kinase in CD28-mediated costimulation. $J$. Biol. Chem. 276, 9003-9008.

Harding, F. A., McArthur, J. G., Gross, J. A., Raulet, D. H., and Allison, J. P. (1992). CD28-mediated signalling co-stimulates murine T cells and prevents induction of anergy in T-cell clones. Nature 356, 607-609.

Harhaj, E. W., and Sun, S. C. (1998). IkappaB kinases serve as a target of CD28 signaling. J. Biol. Chem. 273, 25185-25190.

Healy, A. M., Izmailova, E., Fitzgerald, M., Walker, R., Hattersley, M., Silva, M., Siebert, E., Terkelsen, J., Picarella, D., Pickard, M. D., LeClair, B., Chandra, S., and Jaffee, B. (2006). PKC-theta-deficient mice are protected from Th1-dependent antigeninduced arthritis. J. Immunol. 177, 1886-1893.

Ho, C., Slater, S. J., Stagliano, B., and Stubbs, C. D. (2001). The C1 domain of protein kinase $\mathrm{C}$ as a lipid bilayer surface sensing module. Biochemistry 40, 10334-10341.

Hofinger, E., and Sticht, H. (2005). Multiple modes of interaction between Lck and CD28. J. Immunol. 174, 3839-3840; author reply 3840.

Holdorf, A. D., Green, J. M., Levin, S. D., Denny, M. F., Straus, D. B., Link, V., Changelian, P. S., Allen, P. M., and Shaw, A. S. (1999). Proline residues in CD28 and the Src homology (SH)3 domain of Lck are required for T cell costimulation. J. Exp. Med. 190, 375-384.

Holdorf, A. D., Lee, K. H., Burack, W. R., Allen, P. M., and Shaw, A. S. (2002). Regulation of Lck activity by CD4 and CD28 in the immunological synapse. Nat. Immunol. 3, 259-264.

Huang, J., Lo, P. F., Zal, T., Gascoigne, N. R., Smith, B. A., Levin, S. D., and Grey, H. M. (2002). CD28 plays a critical role in the segregation of PKC theta within the immunologic synapse. Proc. Natl. Acad. Sci. U.S.A. 99, 9369-9373.

Hurley, J. H., Newton, A. C., Parker, P. J., Blumberg, P. M., and Nishizuka, Y. (1997). Taxonomy and function of $\mathrm{C} 1$ protein kinase $\mathrm{C}$ homology domains. Protein Sci. 6, 477-480.

Hutchcroft, J. E., and Bierer, B. E. (1994). Activation-dependent phosphorylation of the T-lymphocyte surface receptor CD28 and associated proteins. Proc. Natl. Acad. Sci. U.S.A. 91, 3260-3264.

Inoue, M., Kishimoto, A., Takai, Y., and Nishizuka, Y. (1977). Studies on a cyclic nucleotide-independent protein kinase and its proenzyme in mammalian tissues. II. Proenzyme and its activation by calciumdependent protease from rat brain. $J$. Biol. Chem. 252, 7610-7616.

Isakov, N., and Altman, A. (1985). Tumor promoters in conjunction with calcium ionophores mimic antigenic stimulation by reactivation of alloantigen-primed murine $\mathrm{T}$ lymphocytes. J. Immunol. 135, 3674 3680.

Isakov, N., and Altman, A. (1987). Human $\mathrm{T}$ lymphocyte activation by tumor promoters: role of protein kinase C. J. Immunol. 138, 31003107.

Isakov, N., and Altman, A. (2002) Protein kinase C-theta in T cell activation. Annu. Rev. Immunol. 20, 761-794.

Isakov, N., Mally, M. I., Scholz, W., and Altman, A. (1987). Tlymphocyte activation: the role of protein kinase $\mathrm{C}$ and the bifurcating inositol phospholipid signal transduction pathway. Immunol. Rev. 95, 89-111.

Jacobs, M. D., and Harrison, S. C. (1998). Structure of an IkappaBalpha/NF-kappaB complex. Cell 95, 749-758.

Jain, J., Loh, C., and Rao, A. (1995). Transcriptional regulation of the IL2 gene. Curr. Opin. Immunol. 7, 333-342.

Jang, M. S., Pan, F., Erickson, L. M., Fisniku, O., Crews, G., Wynn, C., Hong, I. C., Tamura, K., Kobayashi, M., and Jiang, H. (2008). A blocking anti-CD28-specific antibody induces long-term heart allograft survival by suppression of the PKC theta-JNK signal pathway. Transplantation 85 , 1051-1055.

Johnson, J. E., Giorgione, J., and Newton, A. C. (2000). The $\mathrm{Cl}$ and C2 domains of protein kinase C are independent membrane targeting modules, with specificity for phosphatidylserine conferred by the $\mathrm{Cl}$ domain. Biochemistry 39, 1136011369.

Karin, M. (1999). How NF-kappaB is activated: the role of the IkappaB kinase (IKK) complex. Oncogene 18, 6867-6874.

Kariv, I., Truneh, A., and Sweet, R. W. (1996). Analysis of the site of interaction of CD28 with its counterreceptors CD80 and CD86 and correlation with function. J. Immunol. 157 29-38.
Khan, A. A., Steiner, J. P., Klein, M. G., Schneider, M. F., and Snyder, S. H. (1992). IP3 receptor: localization to plasma membrane of $\mathrm{T}$ cells and cocapping with the $\mathrm{T}$ cell receptor. Science 257, 815-818.

Khoshnan, A., Bae, D., Tindell, C. A., and Nel, A. E. (2000). The physical association of protein kinase $\mathrm{C}$ theta with a lipid raft-associated inhibitor of kappa B factor kinase (IKK) complex plays a role in the activation of the NF-kappa B cascade by TCR and CD28. J. Immunol. 165 , 6933-6940.

King, C. L., Xianli, J., June, C. H., Abe, R., and Lee, K. P. (1996). CD28deficient mice generate an impaired Th2 response to Schistosoma mansoni infection. Eur. J. Immunol. 26, 2448-2455.

King, P. D., Sadra, A., Teng, J. M., Xiao-Rong, L., Han, A., Selvakumar, A., August, A., and Dupont, B. (1997). Analysis of CD28 cytoplasmic tail tyrosine residues as regulators and substrates for the protein tyrosine kinases, EMT and LCK. J. Immunol. 158, 580-590.

Kishimoto, A., Takai, Y., Mori, T., Kikkawa, U., and Nishizuka, Y. (1980). Activation of calcium and phospholipid-dependent protein kinase by diacylglycerol, its possible relation to phosphatidylinositol turnover. J. Biol. Chem. 255, 2273 2276.

Kondo, S., Kooshesh, F., Wang, B. Fujisawa, H., and Sauder, D. N. (1996). Contribution of the CD28 molecule to allergic and irritantinduced skin reactions in $\mathrm{CD} 28^{-/-}$ mice. J. Immunol. 157, 4822-4829.

Kong, K. F., Yokosuka, T., CanonigoBalancio, A. J., Isakov, N., Saito, T. and Altman, A. (2011). A novel motif in the V3 domain of protein kinase C-theta (PKC-theta) determines its immunological synapse localization and functions in $\mathrm{T}$ cells via association with CD28. Nat. Immunol. 1105-1112.

Krinzman, S. J., De Sanctis, G. T., Cernadas, M., Mark, D., Wang, Y., Listman, J., Kobzik, L., Donovan, C., Nassr, K., Katona, I., Christiani, D. C., Perkins, D. L., and Finn, P. W. (1996). Inhibition of T cell costimulation abrogates airway hyperresponsiveness in a murine model. J. Clin. Invest. 98, 2693-2699.

Kwon, M. J., Ma, J., Ding, Y., Wang, R., and Sun, Z. (2012). Protein kinase Ctheta promotes Th17 differentiation via upregulation of Stat3. J. Immunol. 188, 5887-5897.

Lamba, V., and Ghosh, I. (2012). New directions in targeting protein kinases: focusing upon true allosteric and bivalent inhibitors. Curr. Pharm. Des. 18, 2936-2945.

Li, C. R., and Berg, L. J. (2005). Itk is not essential for CD28 signaling in naive T cells. J. Immunol. 174, 4475-4479.

Li, Y., Hu, J., Vita, R., Sun, B., Tabata, H., and Altman, A. (2004). SPAK kinase is a substrate and target of PKCtheta in T-cell receptor-induced AP-1 activation pathway. EMBO J. 23, 1112-1122.

Liao, X. C., Fournier, S., Killeen, N., Weiss, A., Allison, J. P., and Littman, D. R. (1997). Itk negatively regulates induction of $\mathrm{T}$ cell proliferation by CD28 costimulation. J. Exp. Med. 186, 221-228.

Lin, X., O'Mahony, A., Mu, Y., Geleziunas, R., and Greene, W. C. (2000). Protein kinase C-theta participates in NF-kappaB activation induced by CD3-CD28 costimulation through selective activation of IkappaB kinase beta. Mol. Cell Biol. 20, 2933-2940.

Linsley, P. S., and Nadler, S. G. (2009). The clinical utility of inhibiting CD28-mediated costimulation. Immunol. Rev. 229, 307-321.

Liu, Y., Liu, Y. C., Meller, N., Giampa, L., Elly, C., Doyle, M., and Altman, A. (1999). Protein kinase C activation inhibits tyrosine phosphorylation of $\mathrm{Cbl}$ and its recruitment of Src homology 2 domain-containing proteins. J. Immunol. 162, 7095-7101.

Liu, Y., Witte, S., Liu, Y. C., Doyle, M., Elly, C., and Altman, A. (2000). Regulation of protein kinase Ctheta function during $\mathrm{T}$ cell activation by Lck-mediated tyrosine phosphorylation. J. Biol. Chem. 275, 3603-3609.

Lorenzo, P. S., Beheshti, M., Pettit, G. R., Stone, J. C., and Blumberg, P. M. (2000). The guanine nucleotide exchange factor RasGRP is a high affinity target for diacylglycerol and phorbol esters. Mol. Pharmacol. 57, 840-846.

Lucas, P. J., Negishi, I., Nakayama, K., Fields, L. E., and Loh, D. Y. (1995). Naive CD28-deficient T cells can initiate but not sustain an in vitro antigen-specific immune response. J. Immunol. 154, 5757-5768.

Lyakh, L., Ghosh, P., and Rice, N. R. (1997). Expression of NFAT-family proteins in normal human $\mathrm{T}$ cells. Mol. Cell Biol. 17, 2475-2484.

Macian, F., Im, S. H., Garcia-Cozar, F. J., and Rao, A. (2004). T-cell anergy. Curr. Opin. Immunol. 16, 209-216.

Manicassamy, S., Yin, D., Zhang, Z., Molinero, L. L., Alegre, M. L., and Sun, Z. (2008). A critical role for protein kinase C-theta-mediated $\mathrm{T}$ cell 
survival in cardiac allograft rejection. J. Immunol. 181, 513-520.

Marengere, L. E., Okkenhaug, K., Clavreul, A., Couez, D., Gibson, S., Mills, G. B., Mak, T. W. and Rottapel, R. (1997). The SH3 domain of Itk/Emt binds to prolinerich sequences in the cytoplasmic domain of the $\mathrm{T}$ cell costimulatory receptor CD28. J. Immunol. 159, 3220-3229.

Marsland, B. J., Nembrini, C., Grun, K., Reissmann, R., Kurrer, M., Leipner, C., and Kopf, M. (2007). TLR ligands act directly upon $\mathrm{T}$ cells to restore proliferation in the absence of protein kinase C-theta signaling and promote autoimmune myocarditis. $J$. Immunol. 178, 3466-3473.

Marsland, B. J., Nembrini, C., Schmitz, N., Abel, B., Krautwald, S., Bachmann, M. F., and Kopf, M. (2005). Innate signals compensate for the absence of PKC-\{theta $\}$ during in vivo $\mathrm{CD} 8(+) \mathrm{T}$ cell effector and memory responses. Proc. Natl. Acad. Sci. U.S.A. 102, 14374-14379.

Marsland, B. J., Soos, T. J., Spath, G., Littman, D. R., and Kopf, M. (2004). Protein kinase $\mathrm{C}$ theta is critical for the development of in vivo $\mathrm{T}$ helper (Th) 2 cell but not Th1 cell responses. J. Exp. Med. 200, 181-189.

Matsumoto, R., Wang, D., Blonska, M., Li, H., Kobayashi, M., Pappu, B., Chen, Y., Wang, D., and Lin, X. (2005). Phosphorylation of CARMAl plays a critical role in $\mathrm{T}$ Cell receptor-mediated NF-kappaB activation. Immunity 23 , 575-585.

McAllister-Lucas, L. M., Inohara, N., Lucas, P. C., Ruland, J., Benito, A., Li, Q., Chen, S., Chen, F. F., Yamaoka, S., Verma, I. M., Mak, T. W., and Nunez, G. (2001). Bimp1, a MAGUK family member linking protein kinase $\mathrm{C}$ activation to Bcl10-mediated NFkappaB induction. J. Biol. Chem. 276, 30589-30597.

Meller, N., Altman, A., and Isakov, N. (1998). New perspectives on PKCtheta, a member of the novel subfamily of protein kinase C. Stem Cells 16, 178-192.

Meller, N., Elitzur, Y., and Isakov, N. (1999). Protein kinase C-theta distribution analysis in hematopoietic cells: proliferating $\mathrm{T}$ cells exhibit high proportions of PKC-theta in the particulate fraction. Cell Immunol. 193, 185-193.

Meller, N., Liu, Y. C., Collins, T. L., Bonnefoy-Berard, N., Baier, G., Isakov, N., and Altman, A. (1996). Direct interaction between protein kinase $\mathrm{C}$ theta (PKC theta) and 14-33 tau in T cells: $14-3-3$ overexpression results in inhibition of PKC theta translocation and function. Mol. Cell Biol. 16, 5782-5791.

Mellor, H., and Parker, P. J. (1998). The extended protein kinase $\mathrm{C}$ superfamily. Biochem. J. 332, 281-292.

Mercurio, F., Zhu, H., Murray, B. W., Shevchenko, A., Bennett, B. L. Li, J., Young, D. B., Barbosa, M., Mann, M., Manning, A., and Rao, A. (1997). IKK-1 and IKK-2: cytokineactivated IkappaB kinases essential for NF-kappaB activation. Science 278, 860-866.

Michel, F., Mangino, G., AttalBonnefoy, G., Tuosto, L., Alcover, A., Roumier, A., Olive, D., and Acuto, O. (2000). CD28 utilizes Vav-1 to enhance TCR-proximal signaling and NF-AT activation. J. Immunol. 165, 3820-3829.

Miller, J., Baker, C., Cook, K., Graf, B., Sanchez-Lockhart, M., Sharp, K. Wang, X., Yang, B., and Yoshida, T. (2009). Two pathways of costimulation through CD28. Immunol. Res. 45, 159-172.

Mittrucker, H. W., Kursar, M., Kohler, A., Hurwitz, R., and Kaufmann, S. H. (2001). Role of CD28 for the generation and expansion of antigen-specific CD8(+) T lymphocytes during infection with Listeria monocytogenes. J. Immunol. 167, 5620-5627.

Monks, C. R., Freiberg, B. A., Kupfer, H., Sciaky, N., and Kupfer, A. (1998). Three-dimensional segregation of supramolecular activation clusters in T cells. Nature 395, 82-86.

Monks, C. R., Kupfer, H., Tamir, I., Barlow, A., and Kupfer, A. (1997). Selective modulation of protein kinase Ctheta during T-cell activation. Nature 385, 83-86.

Nalefski, E. A., and Falke, J. J. (1996). The C2 domain calciumbinding motif: structural and functional diversity. Protein Sci. 5, 23752390.

Newton, A. C. (1995). Protein kinase C: structure, function, and regulation. J. Biol. Chem. 270, 28495-28498.

Nishizuka, Y. (1984). Turnover of inositol phospholipids and signal transduction. Science 225, 1365-1370.

Ohayon, A., Dong, G., and Isakov, N. (2007). "Involvement of PKC $\theta$ in $\mathrm{CD} 4+\mathrm{T}$ cell polarization and mouse resistance to cutaneous Leishmaniasis," in Lymphocyte Activation and Signal Transduction, ed. N. Isakov (Trivandrum: Transworld Research Network), 221-238.

Okkenhaug, K., and Rottapel, R. (1998). Grb2 forms an inducible protein complex with CD28 through a Src homology 3 domain-proline interaction. J. Biol. Chem. 273, 21194 21202.

Osada, S., Mizuno, K., Saido, T. C. Suzuki, K., Kuroki, T., and Ohno, S. (1992). A new member of the protein kinase C family, nPKC theta, predominantly expressed in skeletal muscle. Mol. Cell Biol. 12, 39303938.

Pages, F., Ragueneau, M., Rottapel, R., Truneh, A., Nunes, J., Imbert J., and Olive, D. (1994). Binding of phosphatidylinositol-3-OH kinase to CD28 is required for T-cell signalling. Nature 369, 327-329.

Paige, L. A., Nadler, M. J., Harrison, M. L., Cassady, J. M., and Geahlen, R. L. (1993). Reversible palmitoylation of the protein-tyrosine kinase p56lck. $J$. Biol. Chem. 268, 8669-8674.

Pfeifhofer, C., Kofler, K., Gruber, T., Tabrizi, N. G., Lutz, C., Maly, K., Leitges, M., and Baier, G. (2003). Protein kinase $\mathrm{C}$ theta affects $\mathrm{Ca} 2+$ mobilization and NFAT cell activation in primary mouse T cells. J. Exp. Med. 197, 1525-1535.

Pfeifhofer-Obermair, C., Thuille, N. and Baier, G. (2012). Involvement of distinct PKC gene products in $\mathrm{T}$ cell functions. Front. Immun. 3:220. doi: 10.3389/fimmu.2012.00220

Pietromonaco, S. F., Simons, P. C. Altman, A., and Elias, L. (1998). Protein kinase C-theta phosphorylation of moesin in the actin-binding sequence. J. Biol. Chem. 273, 7594 7603.

Prasad, K. V., Cai, Y. C., Raab, M. Duckworth, B., Cantley, L., Shoelson, S. E., and Rudd, C. E. (1994). T-cell antigen CD28 interacts with the lipid kinase phosphatidylinositol 3-kinase by a cytoplasmic $\operatorname{Tyr}(\mathrm{P})$ Met-Xaa-Met motif. Proc. Natl. Acad. Sci. U.S.A. 91, 2834-2838.

Raab, M., Cai, Y. C., Bunnell, S. C., Heyeck, S. D., Berg, L. J., and Rudd, C. E. (1995). p56Lck and p59Fyn regulate CD28 binding to phosphatidylinositol 3-kinase, growth factor receptor-bound protein GRB-2, and $\mathrm{T}$ cell-specific protein-tyrosine kinase ITK: implications for T-cell costimulation. Proc. Natl. Acad. Sci. U.S.A. 92, 8891-8895.

Regnier, C. H., Song, H. Y., Gao, X., Goeddel, D. V., Cao, Z., and Rothe, M. (1997). Identification and characterization of an IkappaB kinase. Cell 90, 373-383.

Reichert, P., Reinhardt, R. L., Ingulli, E., and Jenkins, M. K. (2001). Cutting edge: in vivo identification of TCR redistribution and polarized IL2 production by naive CD4 T cells. J. Immunol. 166, 4278-4281.
Ribot, J. C., debarros, A., and SilvaSantos, B. (2011). Searching for "signal 2": costimulation requirements of gamma/delta T cells. Cell. Mol. Life Sci. 68, 2345-2355.

Rincon, M., and Flavell, R. A. (1994). AP-1 transcriptional activity requires both T-cell receptor-mediated and co-stimulatory signals in primary $\mathrm{T}$ lymphocytes. EMBO J. 13, 43704381.

Ron, D., Napolitano, E. W., Voronova, A., Vasquez, N. J., Roberts, D. N., Calio, B. L., Caothien, R. H., Pettiford, S. M., Wellik, S., Mandac, J. B., and Kauvar, L. M. (1999). Direct interaction in T-cells between thetaPKC and the tyrosine kinase p59fyn. J. Biol. Chem. 274, 1900319010.

Rosse, C., Linch, M., Kermorgant, S., Cameron, A. J., Boeckeler, K., and Parker, P. J. (2010). PKC and the control of localized signal dynamics. Nat. Rev. Mol. Cell Biol. 11, 103-112.

Rudd, C. E., Anderson, P., Morimoto, C., Streuli, M., and Schlossman, S. F. (1989). Molecular interactions, T-cell subsets and a role of the CD4/CD8:p56lck complex in human T-cell activation. Immunol. Rev. 111, 225-266.

Rudd, C. E., Trevillyan, J. M., Dasgupta, J. D., Wong, L. L., and Schlossman, S. F. (1988). The CD4 receptor is complexed in detergent lysates to a protein-tyrosine kinase (pp58) from human T lymphocytes. Proc. Natl. Acad. Sci. U.S.A. 85, 5190-5194.

Ruefli-Brasse, A. A., French, D. M., and Dixit, V. M. (2003). Regulation of NF-kappaB-dependent lymphocyte activation and development by paracaspase. Science 302, 1581-1584.

Ruland, J., Duncan, G. S., Elia, A., del Barco Barrantes, I., Nguyen, L., Plyte, S., Millar, D. G., Bouchard, D., Wakeham, A., Ohashi, P. S., and Mak, T. W. (2001). Bcl10 is a positive regulator of antigen receptor-induced activation of NF-kappaB and neural tube closure. Cell 104, 33-42.

Ruland, J., Duncan, G. S., Wakeham, A., and Mak, T. W. (2003). Differential requirement for Malt1 in $\mathrm{T}$ and $\mathrm{B}$ cell antigen receptor signaling. Immunity 19, 749-758.

Rulifson, I. C., Sperling, A. I., Fields, P. E., Fitch, F. W., and Bluestone, J. A. (1997). CD28 costimulation promotes the production of Th2 cytokines. J. Immunol. 158, 658-665. Sadra, A., Cinek, T., Arellano, J. L., Shi, J., Truitt, K. E., and Imboden, J. B. (1999). Identification of tyrosine phosphorylation sites in the CD28 
cytoplasmic domain and their role in the costimulation of Jurkat T cells. $J$. Immunol. 162, 1966-1973.

Salek-Ardakani, S., So, T., Halteman, B. S., Altman, A., and Croft, M. (2004). Differential regulation of Th2 and Th1 lung inflammatory responses by protein kinase $\mathrm{C}$ theta. J. Immunol. 173, 6440-6447.

Salek-Ardakani, S., So, T., Halteman, B. S., Altman, A., and Croft, M. (2005). Protein kinase Ctheta controls Thl cells in experimental autoimmune encephalomyelitis. J. Immunol. 175 , 7635-7641.

Salomon, B., and Bluestone, J. A. (2001). Complexities of CD28/B7: CTLA-4 costimulatory pathways in autoimmunity and transplantation. Annu. Rev. Immunol. 19, 225-252.

Sanchez-Lockhart, M., Marin, E., Graf, B., Abe, R., Harada, Y., Sedwick, C. E., and Miller, J. (2004). Cutting edge: CD28-mediated transcriptional and posttranscriptional regulation of IL-2 expression are controlled through different signaling pathways. J. Immunol. 173, 7120-7124.

Schmidt-Supprian, M., Tian, J., Grant, E. P., Pasparakis, M., Maehr, R., Ovaa, H., Ploegh, H. L., Coyle, A. J., and Rajewsky, K. (2004). Differential dependence of CD4+CD25+ regulatory and natural killer-like $\mathrm{T}$ cells on signals leading to NF-kappaB activation. Proc. Natl. Acad. Sci. U.S.A. 101, 4566-4571.

Schneider, H., Cai, Y. C., Prasad, K. V., Shoelson, S. E., and Rudd, C. E. (1995). T cell antigen CD28 binds to the GRB-2/SOS complex, regulators of p21ras. Eur. J. Immunol. 25, 1044-1050.

Schweitzer, A. N., Borriello, F., Wong, R. C., Abbas, A. K., and Sharpe, A. H. (1997). Role of costimulators in T cell differentiation: studies using antigenpresenting cells lacking expression of CD80 or CD86. J. Immunol. 158, 2713-2722.

Shahinian, A., Pfeffer, K., Lee, K. P., Kundig, T. M., Kishihara, K., Wakeham, A., Kawai, K., Ohashi, P. S., Thompson, C. B., and Mak, T. W. (1993). Differential T cell costimulatory requirements in CD28-deficient mice. Science 261, 609-612.

Smith, B. L., Krushelnycky, B. W., Mochly-Rosen, D., and Berg, P. (1996). The HIV nef protein associates with protein kinase $\mathrm{C}$ theta. $J$. Biol. Chem. 271, 16753-16757.

Sommer, K., Guo, B., Pomerantz, J. L., Bandaranayake, A. D., MorenoGarcia, M. E., Ovechkina, Y. L., and Rawlings, D. J. (2005). Phosphorylation of the CARMA1 linker controls
NF-kappaB activation. Immunity 23, 561-574.

Songyang, Z., Shoelson, S. E., Chaudhuri, M., Gish, G., Pawson, T., Haser, W. G., King, F., Roberts, T., Ratnofsky, S., Lechleider, R. J., Neel, B. G., Birge, R. B., Fajardo, J. E., Chou, M. M., Hanafusa, H., Schaffhausen, B., and Cantley, L. C. (1993). $\mathrm{SH} 2$ domains recognize specific phosphopeptide sequences. Cell 72 , 767-778.

Su, B., Jacinto, E., Hibi, M., Kallunki, T., Karin, M., and Ben-Neriah, Y. (1994). JNK is involved in signal integration during costimulation of $\mathrm{T}$ lymphocytes. Cell 77 , 727-736.

Sun, Z., Arendt, C. W., Ellmeier, W., Schaeffer, E. M., Sunshine, M. J., Gandhi, L., Annes, J., Petrzilka, D., Kupfer, A., Schwartzberg, P. L., and Littman, D. R. (2000). PKCtheta is required for TCR-induced NF-kappaB activation in mature but not immature T lymphocytes. Nature 404, 402-407.

Sutcliffe, E. L., Bunting, K. L., He, Y. Q., Li, J., Phetsouphanh, C., Seddiki, N., Zafar, A., Hindmarsh, E. J., Parish, C. R., Kelleher, A. D., McInnes, R. L., Taya, T., Milburn, P. J., and Rao, S. (2011). Chromatinassociated protein kinase C-theta regulates an inducible gene expression program and microRNAs in human T lymphocytes. Mol. Cell 41, 704-719.

Takai, Y., Kishimoto, A., Iwasa, Y., Kawahara, Y., Mori, T., and Nishizuka, Y. (1979). Calcium-dependent activation of a multifunctional protein kinase by membrane phospholipids. J. Biol. Chem. 254, 3692-3695.

Takeda, K., Harada, Y., Watanabe, R., Inutake, Y., Ogawa, S., Onuki, K., Kagaya, S., Tanabe, K., Kishimoto, H., and Abe, R. (2008). CD28 stimulation triggers NF-kappaB activation through the CARMA1-PKCthetaGrb2/Gads axis. Int. Immunol. 20, 1507-1515.

Tan, S. L., Zhao, J., Bi, C., Chen, X. C., Hepburn, D. L., Wang, J., Sedgwick, J. D., Chintalacharuvu, S. R., and Na, S. (2006). Resistance to experimental autoimmune encephalomyelitis and impaired IL-17 production in protein kinase $\mathrm{C}$ theta-deficient mice. $J$. Immunol. 176, 2872-2879.

Tavano, R., Contento, R. L., Baranda, S. J., Soligo, M., Tuosto, L., Manes, S., and Viola, A. (2006). CD28 interaction with filamin-A controls lipid raft accumulation at the T-cell immunological synapse. Nat. Cell Biol. 8, 1270-1276.
Tavano, R., Gri, G., Molon, B., Marinari, B., Rudd, C. E., Tuosto. L. and Viola, A. (2004). CD28 and lipid rafts coordinate recruitment of Lck to the immunological synapse of human T lymphocytes. J. Immunol. 173, 5392-5397.

Teng, J. M., King, P. D., Sadra, A., Liu, X., Han, A., Selvakumar, A., August, A., and Dupont, B. (1996). Phosphorylation of each of the distal three tyrosines of the CD28 cytoplasmic tail is required for CD28-induced T cell IL-2 secretion. Tissue Antigens 48, 255-264.

Thompson, C. B., Lindsten, T., Ledbetter, J. A., Kunkel, S. L., Young, H. A., Emerson, S. G., Leiden, J. M., and June, C. H. (1989). CD28 activation pathway regulates the production of multiple T-cell-derived lymphokines/cytokines. Proc. Natl. Acad. Sci. U.S.A. 86, 1333-1337.

Truitt, K. E., Hicks, C. M., and Imboden, J. B. (1994). Stimulation of CD28 triggers an association between CD28 and phosphatidylinositol 3-kinase in Jurkat T cells. J. Exp. Med. 179, 1071-1076.

Truneh, A., Albert, F., Golstein, P., and Schmitt-Verhulst, A. M. (1985). Early steps of lymphocyte activation bypassed by synergy between calcium ionophores and phorbol ester. Nature 313, 318-320.

Truneh, A., Reddy, M., Ryan, P., Lyn, S. D., Eichman, C., Couez, D., Hurle, M. R., Sekaly, R. P., Olive, D., and Sweet, R. (1996). Differential recognition by CD28 of its cognate counter receptors CD80 (B7.1) and B70 (B7.2): analysis by site directed mutagenesis. Mol. Immunol. 33, 321-334.

Tseng, S. Y., Waite, J. C., Liu, M., Vardhana, S., and Dustin, M. L. (2008). $\mathrm{T}$ cell-dendritic cell immunological synapses contain TCR-dependent CD28-CD80 clusters that recruit protein kinase C theta. J. Immunol. 181, 4852-4863.

Valenzuela, J. O., Iclozan, C., Hossain, M. S., Prlic, M., Hopewell, E., Bronk, C. C., Wang, J., Celis, E., Engelman, R. W., Blazar, B. R., Bevan, M. J., Waller, E. K., Yu, X. Z., and Beg, A. A. (2009). PKCtheta is required for alloreactivity and GVHD but not for immune responses toward leukemia and infection in mice. J. Clin. Invest. 119, 3774-3786.

Vallejo, A. N. (2005). CD28 extinction in human $\mathrm{T}$ cells: altered functions and the program of T-cell senescence. Immunol. Rev. 205, 158-169.

Vardhana, S., Choudhuri, K., Varma, R., and Dustin, M. L. (2010). Essential role of ubiquitin and
TSG101 protein in formation and function of the central supramolecular activation cluster. Immunity 32 , 531-540.

Veillette, A., Bookman, M. A., Horak, E. M., and Bolen, J. B. (1988). The CD4 and CD8 T cell surface antigens are associated with the internal membrane tyrosine-protein kinase p56lck. Cell 55, 301-308.

Via, C. S., Rus, V., Nguyen, P., Linsley, P., and Gause, W. C. (1996). Differential effect of CTLA4Ig on murine graft-versus-host disease (GVHD) development: CTLA4Ig prevents both acute and chronic GVHD development but reverses only chronic GVHD. J. Immunol. 157, 4258-4267.

Viola, A., Schroeder, S., Sakakibara, Y., and Lanzavecchia, A. (1999). T lymphocyte costimulation mediated by reorganization of membrane microdomains. Science 283, 680-682.

Witte, S., Villalba, M., Bi, K., Liu, Y., Isakov, N., and Altman, A. (2000). Inhibition of the c-Jun N-terminal kinase/AP-1 and NFkappaB pathways by PICOT, a novel protein kinase $\mathrm{C}$-interacting protein with a thioredoxin homology domain. J. Biol. Chem. 275, 19021909.

Wulfing, C., and Davis, M. M. (1998). A receptor/cytoskeletal movement triggered by costimulation during $\mathrm{T}$ cell activation. Science 282, 22662269.

Xue, L., Morris, S. W., Orihuela, C., Tuomanen, E., Cui, X., Wen, R., and Wang, D. (2003). Defective development and function of Bcl10deficient follicular, marginal zone and B1 B cells. Nat. Immunol. 4, 857-865.

Yang, W. C., and Olive, D. (1999). Tec kinase is involved in transcriptional regulation of IL- 2 and IL-4 in the CD28 pathway. Eur. J. Immunol. 29, 1842-1849.

Yokosuka, T., Kobayashi, W., SakataSogawa, K., Takamatsu, M., Hashimoto-Tane, A., Dustin, M. L., Tokunaga, M., and Saito, T. (2008). Spatiotemporal regulation of $\mathrm{T}$ cell costimulation by TCR-CD28 microclusters and protein kinase $\mathrm{C}$ theta translocation. Immunity 29, 589-601.

Yokosuka, T., Kobayashi, W., Takamatsu, M., Sakata-Sogawa, K., Zeng, H., Hashimoto-Tane, A., Yagita, H., Tokunaga, M., and Saito, T. (2010). Spatiotemporal basis of CTLA- 4 costimulatory molecule-mediated negative regulation of $\mathrm{T}$ cell activation. Immunity 33, 326-339. 
Yokosuka, T., Sakata-Sogawa, K., Kobayashi, W., Hiroshima, M., Hashimoto-Tane, A., Tokunaga, M., Dustin, M. L., and Saito, T. (2005). Newly generated $\mathrm{T}$ cell receptor microclusters initiate and sustain $\mathrm{T}$ cell activation by recruitment of Zap70 and SLP-76. Nat Immunol 6, 1253-1262.

Zanin-Zhorov, A., Ding, Y., Kumari, S., Attur, M., Hippen, K. L., Brown, M., Blazar, B. R., Abramson, S. B., Lafaille, J. J., and Dustin, M. L. (2010). Protein kinase $\mathrm{C}$-theta mediates negative feedback on regulatory $\mathrm{T}$ cell function. Science 328, 372-376.

Zanin-Zhorov, A., Dustin, M. L., and Blazar, B. R. (2011). PKCtheta function at the immunological synapse: prospects for therapeutic targeting. Trends Immunol. 32, 358-363.

zur Hausen, J. D., Burn, P., and Amrein, K. E. (1997). Co-localization of Fyn with CD3 complex, CD45 or CD28 depends on different mechanisms. Eur. J. Immunol. 27, 2643-2649.
Conflict of Interest Statement: The authors declare that the research was conducted in the absence of any com mercial or financial relationships that could be construed as a potential conflict of interest.

Received: 09 July 2012; accepted: 09 August 2012; published online: 22 August 2012.

Citation: Isakov N and Altman A (2012) $P K C$-theta-mediated signal delivery from the TCR/CD28 surface receptors. Front.
Immun. 3:273. doi: 10.3389/fimmu. 2012.00273

This article was submitted to Frontiers in $T$ Cell Biology, a specialty of Frontiers in Immunology.

Copyright (C) 2012 Isakov and Altman. This is an open-access article distributed under the terms of the Creative Commons Attribution License, which permits use, distribution and reproduction in other forums, provided the original authors and source are credited and subject to any copyright notices concerning any third-party graphics etc. 